\title{
The Land Processes Distributed Active Archive Center (LP DAAC)
}

\section{Overview}

Established in 1990, in partnership with the U.S. Geological Survey, the Land Processes Distributed Active Archive Center (LP DAAC) is 1 of 12 DAACs within the National Aeronautics and Space Administration (NASA) Earth Observing System Data and Information System (EOSDIS). The LP DAAC ingests, archives, processes, and distributes NASA Earth science land processes data. The LP DAAC holds more than 2 petabytes $(2,000$ terabytes) of remotely sensed land data that are available to the public at no charge.

\section{LP DAAC Data Types}

The LP DAAC holds data collected by satellite sensors that observe the Earth's land surface. Currently, data archived by the LP DAAC are collected by the Advanced Spaceborne Thermal Emission and Reflection Radiometer (ASTER) and Moderate Resolution Imaging Spectroradiometer (MODIS) sensors onboard the Aqua and Terra satellites, as well as a variety of other datasets from NASA's Making Earth System Data Records for Use in Research Environments (MEaSUREs) and community programs that are generated by selected science investigators. For more information about data products at the LP DAAC, please visit https://lpdaac.usgs.gov/. Check often because the LP DAAC actively archives new datasets!

\section{LP DAAC Data Coverage}

Onboard two satellites with differing orbits, MODIS provides information about the entire Earth every 1 to 2 days. MODIS data are also composited to provide 4-day, 8-day, 16-day, monthly, and yearly snapshots of the Earth. The ASTER sensor has to be tasked to capture an area, which is advantageous for studying specific areas or phenomena or for providing high spatial resolution images during times of natural disasters.

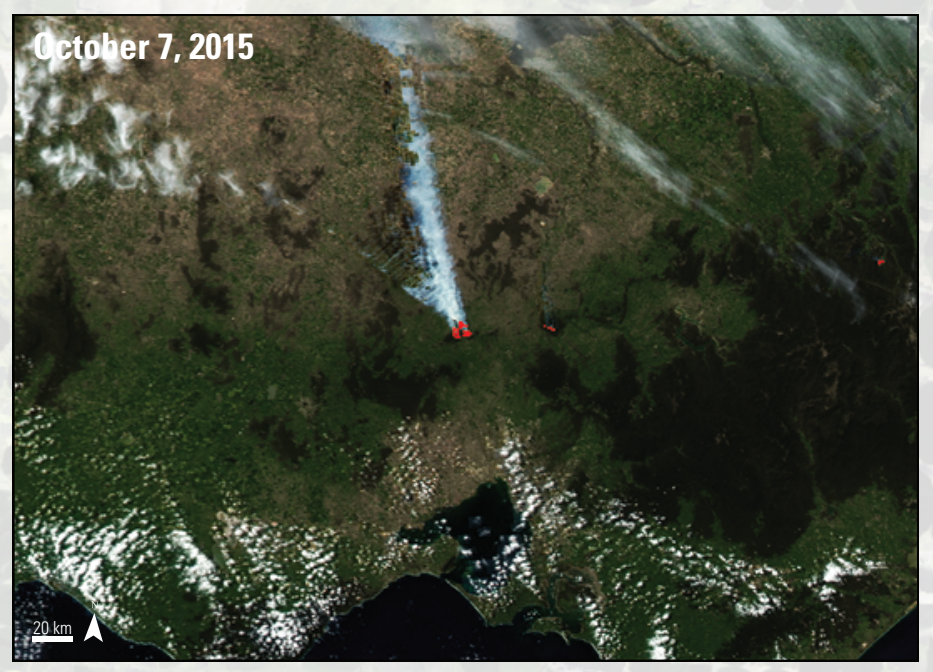

The Aqua Moderate Resolution Imaging Spectroradiometer (MODIS) Thermal Anomalies and Fire Product (in red), overlaid on a true color surface reflectance image, shows wildfires in southeastern Australia, October 7, 2015.

Table 1. Land Processes Distributed Active Archive Center (LP DAAC) data.

[m, meter; MEaSUREs, Making Earth System Data Records for Use in Research Environments; NASA, National Aeronautic and Space Administration; ETM+, Enhanced Thematic Mapper plus]

\begin{tabular}{|c|c|c|c|c|}
\hline Collection name & Data collected by & Temporal coverage & Geographic coverage & Pixel size \\
\hline $\begin{array}{l}\text { Advanced Spaceborne Thermal Emission } \\
\text { and Reflection Radiometer (ASTER) }\end{array}$ & Terra ASTER & 2000-present & Global & $\begin{array}{l}15 \mathrm{~m} ; 30 \mathrm{~m} \\
\quad 90 \mathrm{~m}\end{array}$ \\
\hline $\begin{array}{l}\text { Moderate Resolution Imaging } \\
\text { Spectroradiometer (MODIS) }\end{array}$ & Aqua MODIS and Terra MODIS & $\begin{array}{l}\text { Aqua 2002-present } \\
\text { Terra 2000-present }\end{array}$ & Global & $\begin{array}{l}250 \mathrm{~m} ; 500 \mathrm{~m} \\
1,000 \mathrm{~m} \\
5,600 \mathrm{~m}\end{array}$ \\
\hline $\begin{array}{l}\text { MEaSUREs: NASA Shuttle Radar Topo- } \\
\text { graphy Mission (SRTM) Version } 3\end{array}$ & Space Shuttle Endeavour & February $11-21,2000$ & $60^{\circ} \mathrm{N}$ to $56^{\circ} \mathrm{S}$ & $30 \mathrm{~m} ; 90 \mathrm{~m}$ \\
\hline $\begin{array}{l}\text { MEaSUREs: Web-Enabled Landsat Data } \\
\text { (WELD) }\end{array}$ & Landsat 7 ETM+ & $2002-12$ & $\begin{array}{l}\text { Conterminous United } \\
\text { States and Alaska }\end{array}$ & $30 \mathrm{~m}$ \\
\hline $\begin{array}{l}\text { MEaSUREs: Vegetation Index and } \\
\text { Phenology (VIP) }\end{array}$ & $\begin{array}{l}\text { Terra MODIS, Advanced Very High } \\
\text { Resolution Radiometer (AVHRR), and } \\
\text { Satellite Pour l'Observation de la Terre } \\
\text { (SPOT) }\end{array}$ & $1981-2013$ & Global & $5,600 \mathrm{~m}$ \\
\hline $\begin{array}{l}\text { Community: ASTER Global Emissivity } \\
\text { Dataset (GED) }\end{array}$ & Terra ASTER & $\begin{array}{l}\text { Version 3: } 2000-08 \\
\quad \text { Version 4: } 2000-15\end{array}$ & Global & $\begin{array}{l}100 \mathrm{~m} \\
1,000 \mathrm{~m} \\
5,600 \mathrm{~m}\end{array}$ \\
\hline
\end{tabular}




\section{LP DAAC Data Access}

The Data Pool offers direct download access to most of the data at the LP DAAC. Bulk orders of these data can be downloaded using the DAAC2Disk tool. Users can also access and browse data through NASA's Earthdata Search Client.
The Application for Extracting and Exploring Analysis Ready Samples (AppEEARS) allows access to user-defined samples of data and interactive visualizations of data values. More information about these data access tools is available on the LP DAAC Web site at https://lpdaac.usgs.gov/.

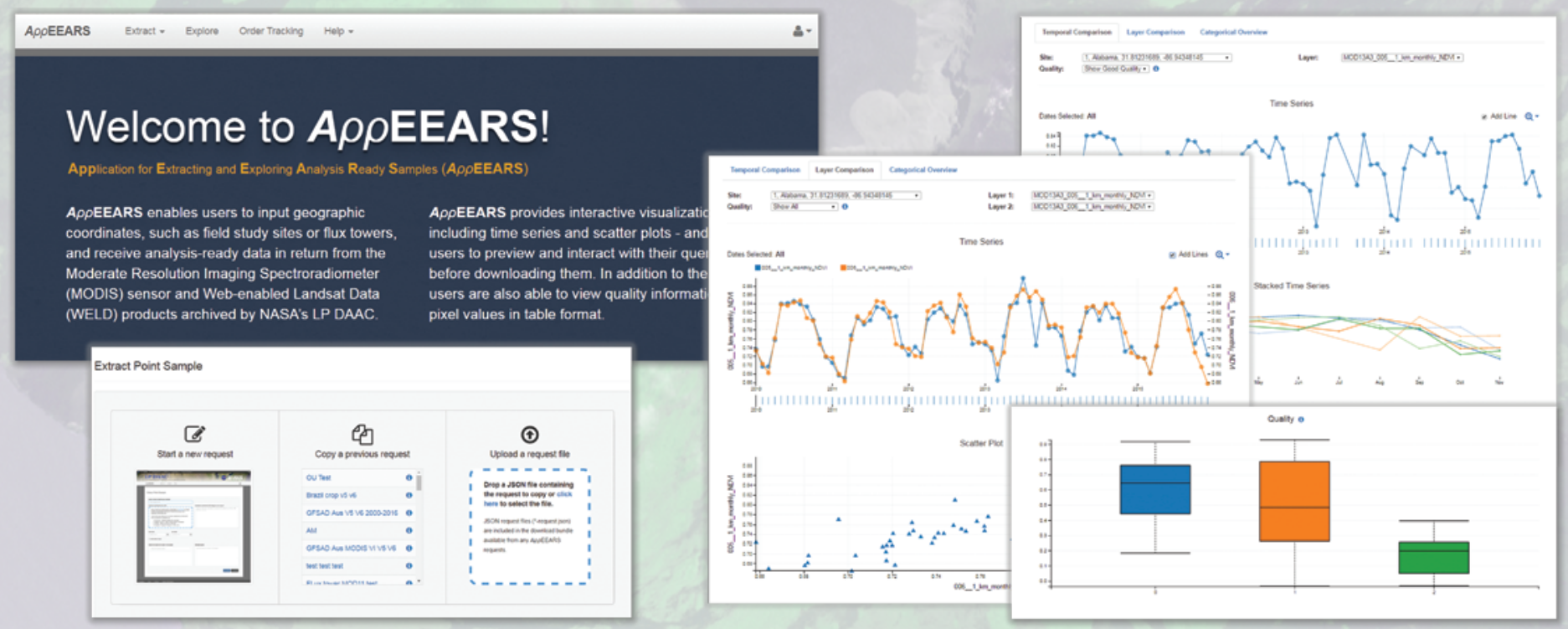

The Land Processes Distributed Active Archive Center's (LP DAAC) Application for Extracting and Exploring Analysis Ready Samples (AppEEARS) application allows users to explore and visualize data values.

\section{LP DAAC Data Applications}

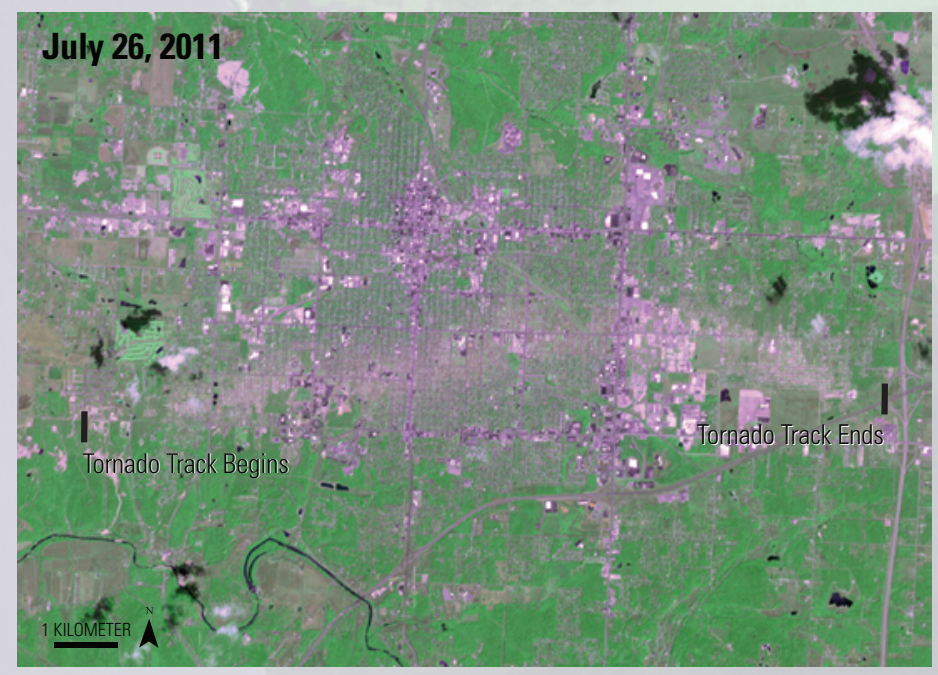

A Terra Advanced Spaceborne Thermal Emission and Reflection Radiometer (ASTER) image of the track of an EF-5 tornado in Joplin, Missouri, July 26, 2011.

Data from the LP DAAC are used in a variety of applications, including geology and soils, agriculture, urban studies, health, vegetation and ecosystem dynamics, volcano and hazards monitoring, natural disasters, hydrology, climate, and land change. These data can help us understand how the Earth works and how it is changing.

\section{Voice: 605-594-6116 \\ Toll Free: 866-573-3222 \\ (866-LPE-DAAC) \\ Fax: 605-594-6963}

LP DAAC Contact Information:
E-mail: LPDAAC@usgs.gov Web: https://lpdaac.usgs.gov/ NASA Earthdata Social Media Facebook: NASAEarthdata Twitter: @NASAEarthdata

\section{About the ASTER L1T Data Product}

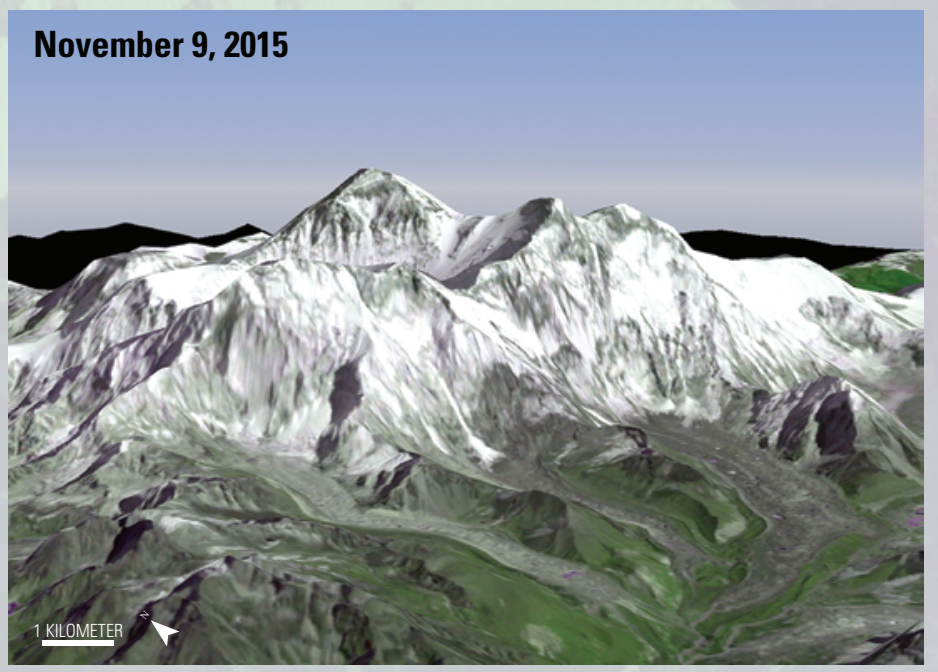

A Terra Advanced Spaceborne Thermal Emission and Reflection Radiometer (ASTER) Precision Terrain Corrected image draped over a digital elevation model of Mount Everest, November 9, 2015.

The Terra ASTER Level 1 Precision Terrain Corrected Registered At-Sensor Radiance (AST_L1T) dataset was created by the LP DAAC. This dataset provides users with a quick turnaround of consistent geographic information system (GIS)-ready data as a multifile product. Terrain-corrected data are useful for monitoring changes on the Earth's surface, including changes in vegetation, ecosystems, and land cover. The data can be used to monitor volcanoes before, during, and after eruptions and to observe changes caused by natural disasters such as floods, wildfires, coastal erosion, earthquakes, and tsunamis. Terrain-corrected data can also be used to understand hydrological processes and map surface soils.

\section{By Danielle K. Golon ${ }^{1}$}

${ }^{1}$ Innovate!, Inc., Work done under contract G15PD00766 for LP DAAC to the U.S. Geological Survey 